OSEANOLOGI DAN LIMNOLOGI DI INDONESIA

Print ISSN: 0125-9830 Online ISSN: 2477-328X

Nomor Akreditasi: 712/AU3/P2MI - LIPI/10/2015

http://jurnal-oldi.or.id

\title{
Komunitas Mangrove di Wilayah Pesisir Pulau Tidore dan Sekitarnya
}

\section{Mangrove Community in Coastal Area of Tidore Islands}

\author{
Doni Nurdiansah ${ }^{1}$ dan I Wayan Eka Dharmawan ${ }^{2}$ \\ ${ }^{1}$ Loka Konservasi Biota Laut LIPI Bitung, \\ ${ }^{2}$ Loka Konservasi Biota Laut LIPI Biak.
}

Email: doni002@lipi.go.id

Submitted 22 March 2016. Reviewed 21 June 2017. Accepted 8 December 2017.

\begin{abstract}
Abstrak
Indonesia memiliki sebaran ekosistem mangrove terluas di dunia. Ekosistem ini menyediakan banyak manfaat langsung maupun tidak langsung bagi masyarakat pesisir. Penelitian tentang kondisi komunitas mangrove di wilayah Pulau Tidore, Halmahera, Ternate dan sekitarnya dilaksanakan pada bulan Agustus 2015, dengan tujuan untuk mengetahui kondisi terkini komunitas mangrove di wilayah ini. Penilaian kondisi mangrove dilakukan dengan cara menganalisis persentase tutupan kanopinya dengan metode Hemispherical Photography (pengambilan foto ke arah vertikal/langit) dan menganalisis persentase pixel dari foto yang diperoleh dengan menggunakan software Image $J$ dan Microsoft Excel. Hasil penelitian menunjukkan kondisi mangrove di kawasan kepulauan pada perairan Pulau Tidore, Halmahera, Ternate dan sekitarnya termasuk dalam kategori tutupan sedang dengan rata-rata persentase tutupan kanopi komunitas sebesar $73.15 \pm 11.78 \%$, nilai rata-rata kerapatan pohon juga termasuk kategori sedang yaitu $1.275 \pm 838$ pohon/ha. Spesies Sonneratia alba (Pulau Maitara, Pulau Tidore, dan Kaiyasa Halmahera Barat) yang paling dominan di sebagian besar hutan bakau. Hal ini didukung oleh tipe substrat mangrove di dalam kawasan yang cenderung pasir lumpuran. Kata kunci: Mangrove, Komunitas, Tutupan Kanopi, Halmahera, Ternate, Tidore
\end{abstract}

\begin{abstract}
Indonesia has the most extensive area of mangrove ecosystem in the world. It bring many direct and indirect benefits for the coastal community. Research on the condition of mangrove communities in Tidore, Halmahera, Ternate Island and surrounding areas was conducted in August 2015, to determine the current condition of mangrove communities in the region. Assessment condition mangrove forest was done by means of analyze the percentage covering canopy with the hemispherical photography methods (photography toward vertical) and analyze the percentage pixels from a photograph obtained by using software image $\mathbf{J}$ and Microsoft Excel. The species Sonneratia alba in the Maitara, Tidore, and Kaiyasa Island West Halmahera is the most dominant.
\end{abstract}

Keywords: Mangrove, Community, Cover Canopy, Halmahera, Ternate, Tidore. 


\section{Pendahuluan}

Wilayah kepulauan Indonesia, sebagai salah satu negara dengan garis pantai terpanjang di dunia, merupakan kawasan yang sangat baik bagi perkembangan komunitas mangrove. Indonesia memiliki luasan ekosistem mangrove yang paling tinggi di dunia, sekitar 3,2 juta hektar atau mencapai 22,6\% dari luas mangrove dunia (FAO 2007; Giri et al. 2011). Hal ini menunjukkan potensi komunitas mangrove di Indonesia yang sangat tinggi secara ekologi serta dalam pemanfaatan secara langsung maupun tidak langsung bagi masyarakat pesisir.

Secara fisik, mangrove memberikan perlindungan bagi masyarakat pesisir dari badai dan tsunami (Giesen et al. 2007; Mitsch and Gosselink 2015; Alongi 2009). Mangrove juga berperan sebagai habitat yang baik bagi fauna darat dan biota laut sebagai sumber keanekaragaman spesies kawasan serta sumber pangan bagi masyarakat. Kayu mangrove bisa dimanfaatkan sebagai bahan konstruksi, perahu dan kayu bakar. (Duke et al. 2007; FAO 2007). Ekosistem mangrove juga merupakan sumber nutrisi maupun energi bagi ekosistem yang berdekatan termasuk ekosistem lamun dan terumbu karang. Saat ini, berbagai penelitian menunjukkan mangrove sebagai salah satu penyerap karbon terbesar di daerah tropis (Cahoon et al. 2003; Bouillon et al. 2008; Nellemann et al. 2009).

Optimalisasi dari fungsi-fungsi ekosistem mangrove dalam suatu kawasan sangat tergantung dari kondisi kesehatan komunitas mangrove. Mangrove yang sehat dapat memberikan fungsi maksimal bagi lingkungan sekitar. Kajian tentang kesehatan ekosistem mangrove telah dikembangkan di Indonesia dan telah terimplementasi pada Program COREMAP CTI dengan pendekatan foto hemispherik serta didukung oleh data komunitas di 30 lokasi mangrove Indonesia (Dharmawan dan Pramudji 2014). Intervensi antropogenik akan dapat terdeteksi dari tutupan kanopi dalam komunitas.

Kawasan kepulauan di sekitar perairan Pulau Tidore merupakan salah satu habitat yang cukup baik untuk pertumbuhan mangrove. Variabilitas geomorfologi pantai yang beragam dan beberapa kawasan terlindung memberikan ruang untuk pertumbuhan mangrove. Karakteristik daratan yang berupa pulau-pulau gunung vulkanik dengan kemiringan curam memberikan ruang yang terbatas bagi pertumbuhan mangrove di dalam kawasan, khususnya di wilayah kepulauan. Saat ini, pembangunan di dalam kawasan berkembang dengan pesat memberikan tekanan yang cukup signifikan bagi keberlangsungan ekosistem. Oleh karena itu, kajian tentang kondisi kesehatan mangrove sangat penting dilakukan sebagai baseline bagi pengelolaan kawasan. Tujuan dari penelitian ini adalah untuk menganalisis status terkini kondisi kesehatan komunitas mangrove pada kawasan kepulauan di Pulau Tidore dan sekitarnya.

\section{Metodologi}

Penelitian dilaksanakan di wilayah kepulauan di perairan Pulau Tidore, Halmahera, Ternate dan sekitarnya pada bulan Agustus 2015. Lokasi dan posisi geografis masing-masing stasiun penelitian ini berdasarkan penelitian sebelumnya yang dilakukan COREMAP pada tahun 2012 hingga tahun 2015 disajikan pada Tabel 1 dan Gambar 1.

Tabel 1. Posisi Geografi, jumlah transek dan karakteristik deskriptif substrat dari setiap lokasi penelitian.

Table 1. Number of transects and substrate characteristic of study sites.

\begin{tabular}{lccccll}
\hline \multirow{2}{*}{ Location } & \multirow{2}{*}{ Sample Id } & \multicolumn{2}{c}{ Coordinat } & \multirow{2}{*}{$\begin{array}{c}\text { Transect } \\
\text { Number }\end{array}$} & \multirow{2}{*}{ Substrate } \\
\cline { 3 - 4 } Ternate Island & N & S & & \\
Maitara Island & TTEM01 & 127.306494 & 0.84243 & 3 & Hard Mud \\
Maitara Island & TTEM02 & 127.36527 & 0.73979 & 3 & Muddy Sand \\
Tidore Island & TTEM03 & 127.37703 & 0.72847 & 3 & Muddy Sand \\
Tidore Island & TTEM04 & 127.38561 & 0.73340 & 1 & Hard Mud \\
Tidore Island & TTEM05 & 127.44931 & 0.74374 & 3 & Muddy Sand \\
Tidore Island & TTEM06 & 127.45433 & 0.73019 & 3 & Muddy Sand \\
Tidore Island & TTEM07 & 127.45923 & 0.71090 & 3 & Muddy Sand \\
Jailolo, Halmahera & TTEM08 & 127.45555 & 0.69485 & 3 & Mud \\
Jailolo, Halmahera & TTEM09 & 127.50044 & 0.86832 & 3 & Mud \\
Dodinga, Halmahera & TTEM10 & 127.50036 & 0.88079 & 3 & Mud \\
Kaiyasa, Halmahera & TTEM11 & 127.63741 & 0.84663 & 3 & Mud \\
\hline
\end{tabular}




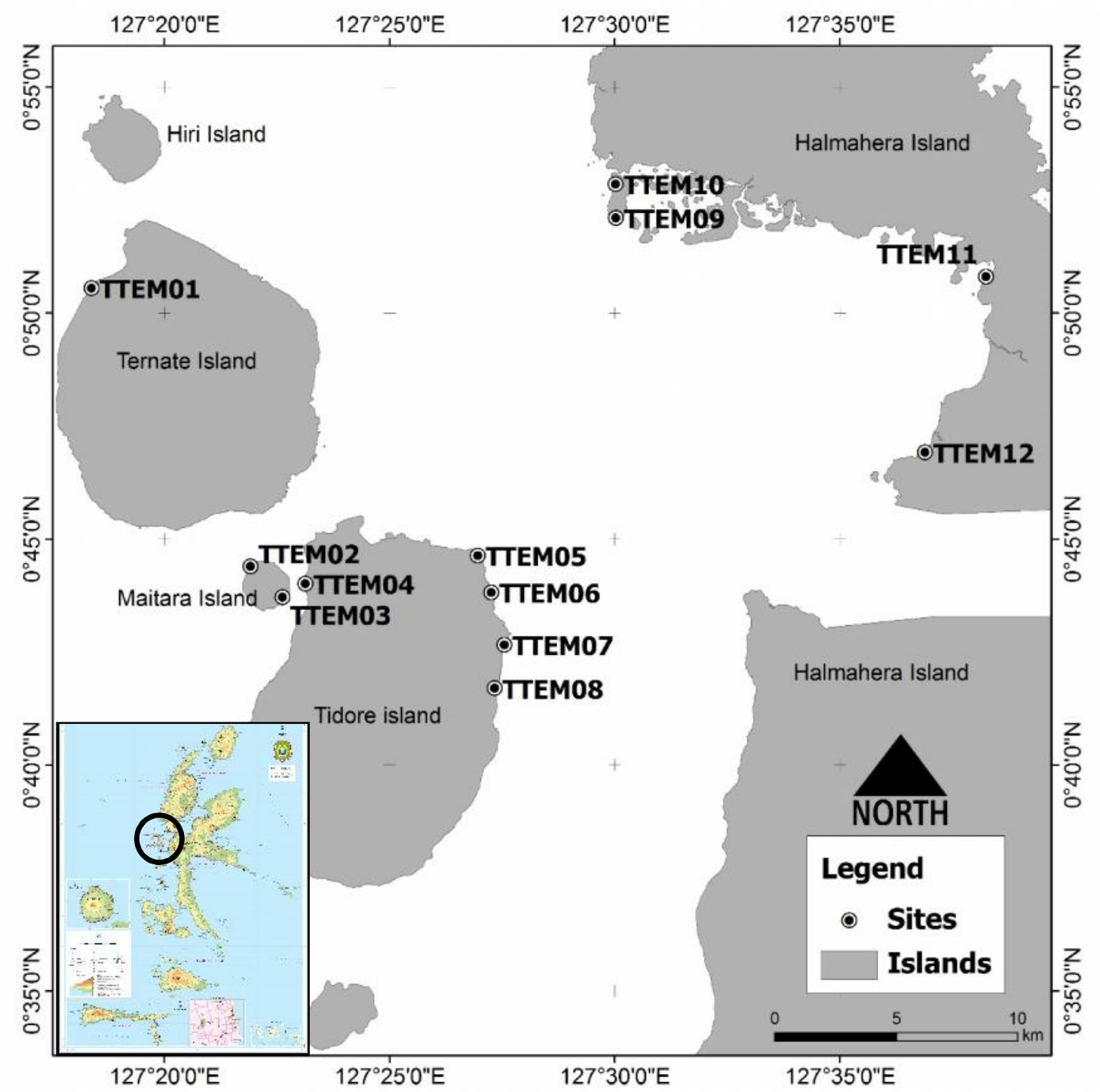

Gambar 1. Sebaran stasiun penelitian mangrove di Pulau Tidore dan kepulauan sekitarnya Figure 1. Mangrove study sites on Tidore island and adjacent islands

\section{Pengambilan data}

Nilai persentase tutupan kanopi komunitas mangrove didekati dengan metode Hemispherical Photography (Dharmawan dan Pramudji 2014). Sebanyak 48 plot berukuran $10 \mathrm{~m}$ x $10 \mathrm{~m}$ pada 12 stasiun penelitian dibuat untuk membatasi area pengambilan foto. Setiap plot dilakukan pengambilan foto sebanyak empat hingga sembilan foto berdasarkan kondisi tutupan kanopi dengan total sebanyak 320 foto hemisphere yang dikoleksi. Dalam setiap plot, lingkar batang pohon diukur sejajar dengan tinggi dada dan diidentifikasi setiap spesies mangrove tersebut berdasarkan Giesen et al. (2006).

\section{Analisis Data}

Foto hemisphere dianalisis dengan menggunakan software ImageJ untuk memperoleh nilai persentase tutupan kanopi komunitas berdasarkan pembagian antara jumlah pixel vegetasi dengan seluruh pixel kemudian dikali 100\% (Dharmawan dan Pramudji 2014). Nilai lingkar batang setiap stasiun penelitian dimasukkan ke dalam template100_10x10 untuk memperoleh nilai kerapatan pohon, jumlah spesies serta indeks nilai penting (INP). Seluruh data univariat (persentase tutupan kanopi komunitas dan kerapatan pohon) dianalisis secara deskriptif untuk memperoleh nilai rata-rata dan standar deviasi. Berdasarkan analisis Kolgomorof-Smirnof, seluruh data terindentifikasi dalam sebaran normal, sehingga analisis ANOVA dan uji Tukey dilakukan untuk mengetahui variansi antar stasiun penelitian. Untuk menganalisis kedekatan antar stasiun, nilai INP setiap spesies dianalisis kemiripannya dengan Eucladian Distances serta ditampilkan dalam matriks mMDS yang disinergikan dengan koefisien korelasi Spearman. 
Intepretasi status kondisi kesehatan komunitas mangrove dilakukan dengan kategori yang telah ditetapkan dalam Keputusan Menteri Lingkungan Hidup No. 201 tahun 2004 tentang Kriteria Baku dan Pedoman Penentuan Kerusakan Mangrove.

\section{Hasil}

Secara keseluruhan, kondisi tutupan mangrove di kawasan Pulau Tidore, Halmahera, Ternate dan sekitarnya termasuk dalam kategori tutupan sedang dengan rata-rata persentase tutupan kanopi sebesar 73,13 $\pm 11,78 \%$ (Gambar 2). Hal ini sangat dipengaruhi oleh kondisi tutupan kanopi pada setiap stasiun penelitian yang tidak memiliki rentang tutupan terendah $(61,02 \pm 21,20 \%$ di TTEM02) sampai tertinggi $(78,93 \pm 11,96 \%$ di TTEM11). Sebanyak lima stasiun pemantauan memiliki kategori persentase tutupan kanopi padat (TTEM 01, 03, 09,
10 dan 11), sedangkan tujuh stasiun lainnya memiliki kategori tutupan sedang (Gambar 2). Nilai simpangan data yang cukup lebar menyebabkan tidak adanya perbedaan nilai tutupan kanopi secara signifikan (ANOVA, $\mathrm{F}=1,654 ; \mathrm{P}=0,125$ ).

Kondisi tutupan mangrove yang cukup baik di kawasan Pulau Tidure dan pulau-pulau disekitarnya juga didukung oleh nilai kerapatan pohonnya. Secara keseluruhan, rata-rata kerapatan pohon mangrove dalam kawasan termasuk dalam kategori sedang, yaitu: $1.275 \pm 838$ pohon/ha. Kerapatan pohon terendah ditemukan pada stasiun TTEM06, yaitu: $667 \pm 296$ pohon/ha, sedangkan yang tertinggi $(1.783 \pm 221$ pohon/ha) ditemukan pada stasiun TTEM04. Walaupun rentang kerapatan cukup lebar, namun tidak ditemukan perbedaan yang signifikan antar stasiun penelitian (ANOVA, $\mathrm{F}=1,782 ; \mathrm{P}=0,094)$.

Tabel 2. Kriteria Baku Kerusakan Mangrove

Table 2. Standard Criteria Mangrove Destruction

\begin{tabular}{|c|c|c|c|}
\hline \multicolumn{2}{|c|}{ Criteria } & Canopy coverage (\%) & Density (tree/ha) \\
\hline \multirow{2}{*}{ Good } & Dense & $\geq 75$ & $\geq 1500$ \\
\hline & Moderate & $\geq 50-<75$ & $\geq 1000-<1500$ \\
\hline $\mathrm{Bad}$ & Sparse & $<50$ & $<1000$ \\
\hline
\end{tabular}

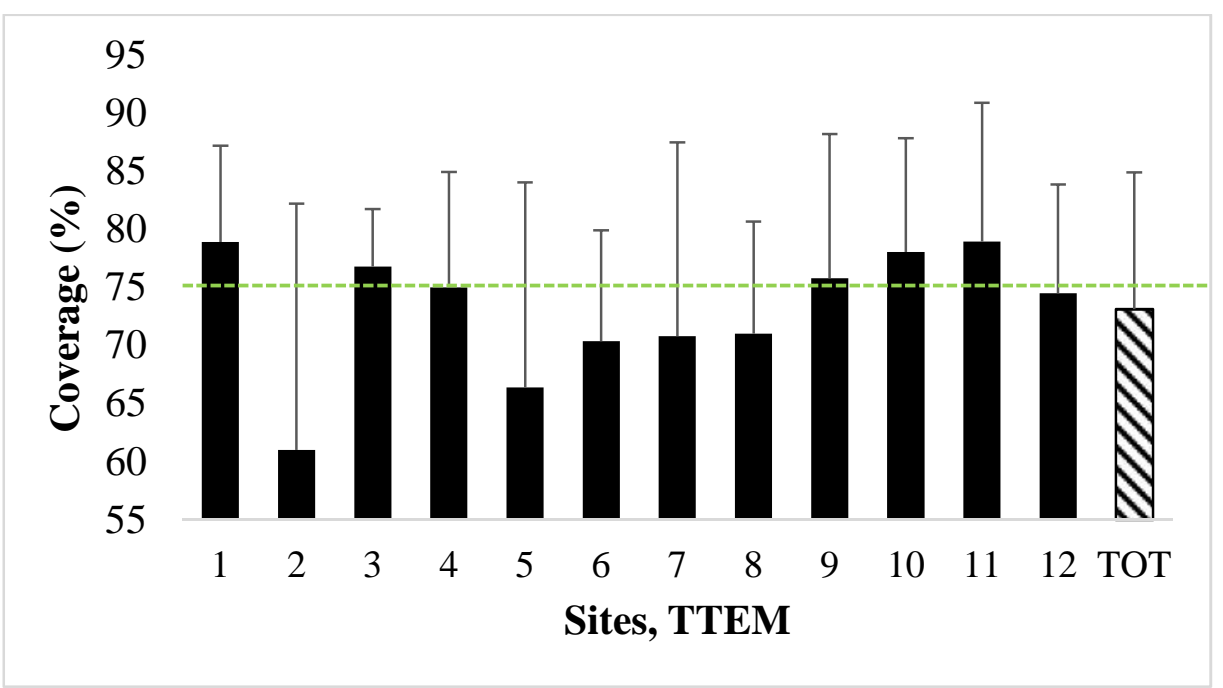

Gambar 2. Persentase tutupan kanopi komunitas mangrove pada setiap stasiun pemantauan (1-12) serta nilai rata-ratanya (TOT). Keterangan: Garis hijau menunjukkan batas antara kategori tutupan sedang $(>50-75 \%)$ dan padat $(>75 \%)$

Figure 2. Percentage of mangrove's canopy community coverage on each sites (1-12) and its total average (TOT). Note: green line represented a border between moderate (>50-75\%) and dense $(>75 \%)$ category of mangrove canopy coverage. 


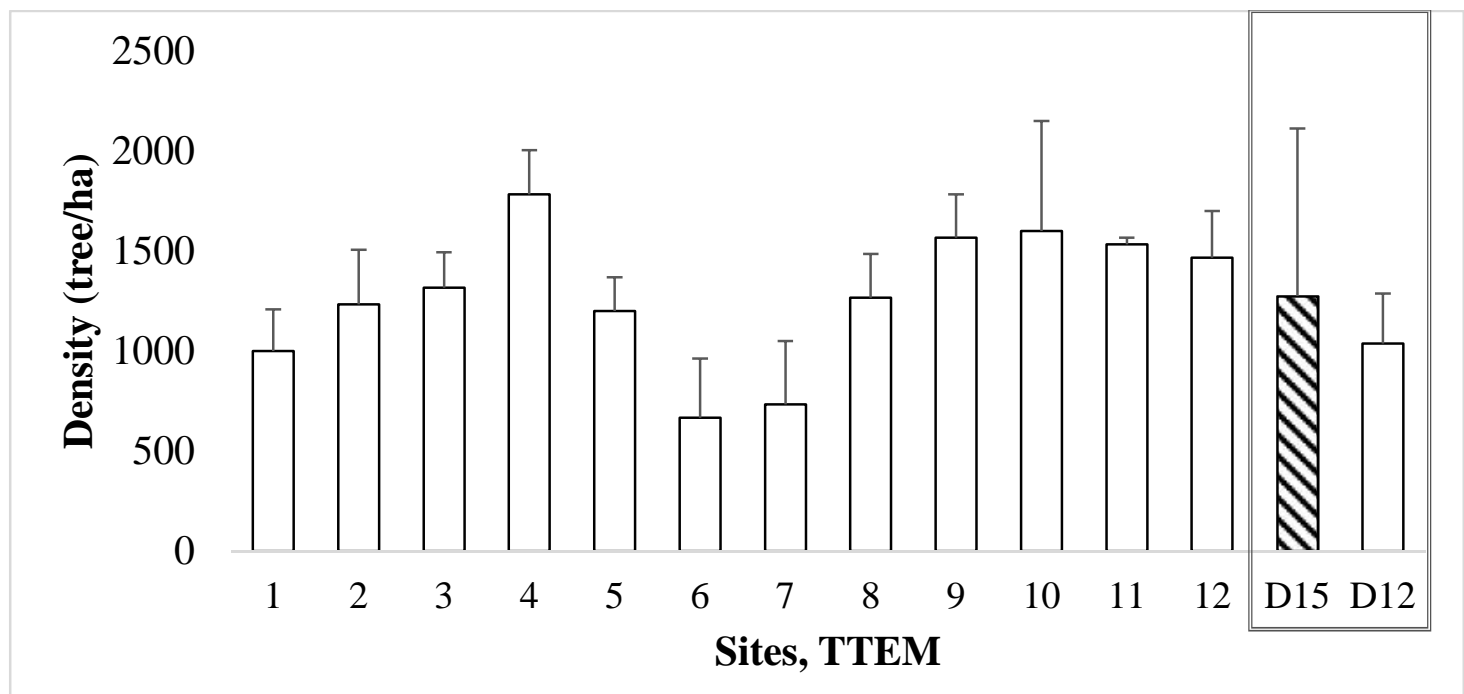

Gambar 3. Kerapatan pohon per hektar pada setiap stasiun penelitian (TTEM 1- TTEM 12) serta nilai rataratanya (D15), dibandingkan dengan tahun 2012 (D12).

Figure 3. Tree density per hectare on each study sites (TTEM 1- TTEM 12) and its total average (D15), compared to year of 2012 (D12)

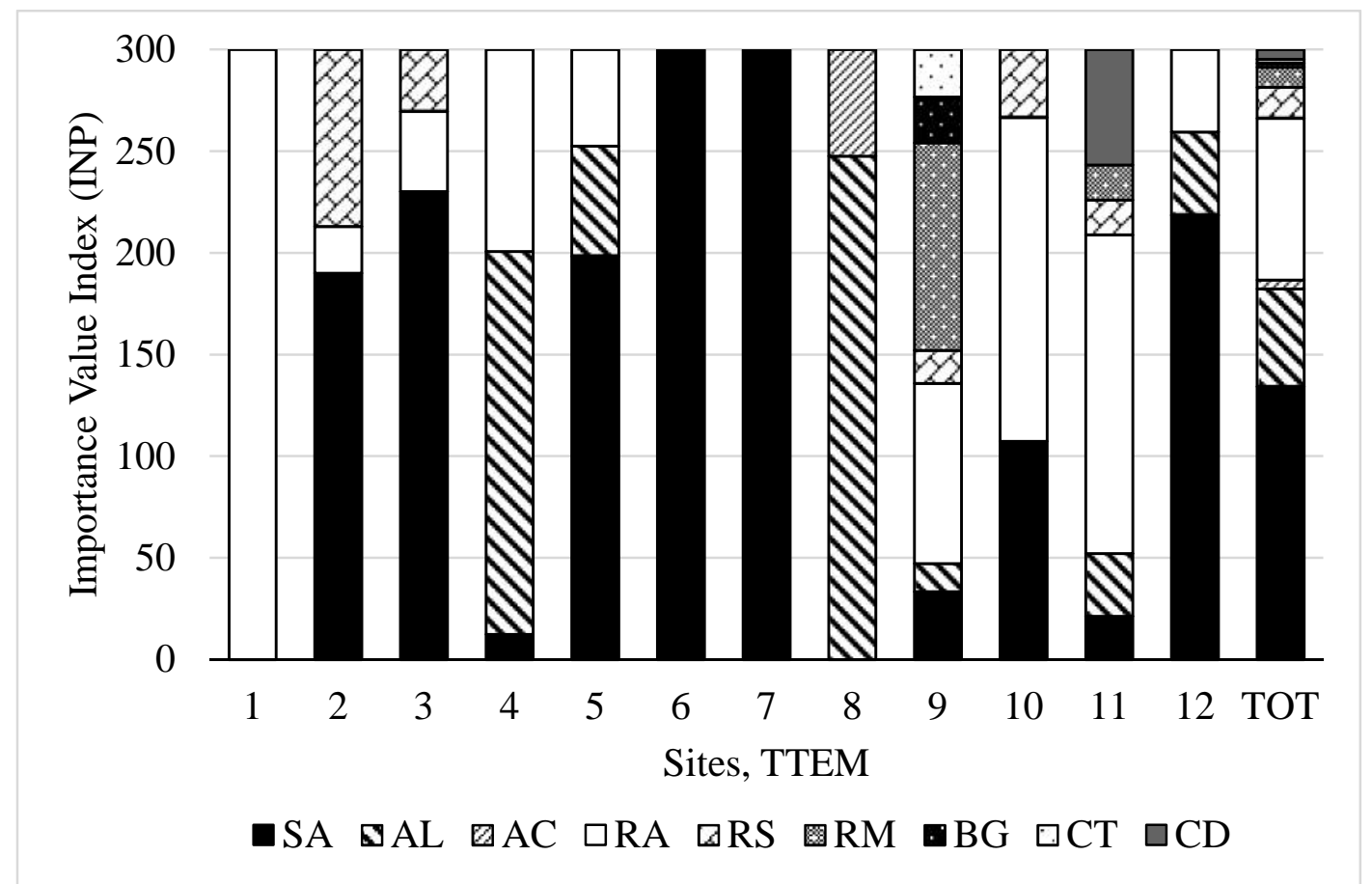

Gambar 4. Indeks nilai penting (INP) setiap spesies pada setiap stasiun penelitian

( $\mathrm{SA}=$ Sonneratia alba $; \mathrm{AL}=$ Avicennia lanata $; \mathrm{AC}=$ Aegiceras corniculatum $; \mathrm{RA}=$ Rhizophora apiculata $; \mathrm{RS}=$ Rhizophora stylosa $; \mathrm{RM}=R$. mucronata $; \mathrm{BG}=$ Bruguiera gymnorrhiza; $\mathrm{CT}=$ Ceriops tagal; $\mathrm{CD}=C$. decandra)

Figure 4. Importance value index (INP) of each species on each study sites

( $\mathrm{SA}=$ Sonneratia alba $; \mathrm{AL}=$ Avicennia lanata $; \mathrm{AC}=$ Aegiceras corniculatum $; \mathrm{RA}=$ Rhizophora apiculata; $\mathrm{RS}=$ Rhizophora stylosa $; \mathrm{RM}=R$. mucronata $; \mathrm{BG}=$ Bruguiera gymnorrhiza; $\mathrm{CT}=$ Ceriops tagal; $\mathrm{CD}=C$. decandra)

Indeks nilai penting (INP) pada setiap spesies dapat menggambarkan dominasi suatu spesies pada setiap stasiun penelitian. Secara keseluruhan, komunitas mangrove di Pulau Tidore dan pulau-pulau sekitarnya didominasi oleh S. alba yang ditunjukkan dari nilai INP tertinggi, yaitu 
134,31\%. Ko-dominansi spesies $R$. apiculata dan $A$. lanata memiliki nilai INP $79,50 \%$ dan $48,00 \%$ (Gambar 4). Ordinasi seluruh stasiun penelitian dengan analisis MDS menunjukkan pengelompokan stasiun TTEM02, 03, 06, 07 dan 12 yang disebabkan oleh dominansi S. alba (Gambar 5). Dominansi pada spesies A. lanata menyebabkan ordinasi yang cukup jauh pada stasiun TTEM04 dan TTEM08. Stasiun TTEM01, tidak memiliki kemiripan komposisi spesies dengan stasiun lainnya, hal ini disebabkan oleh dominansi monospesies $R$. apiculata.

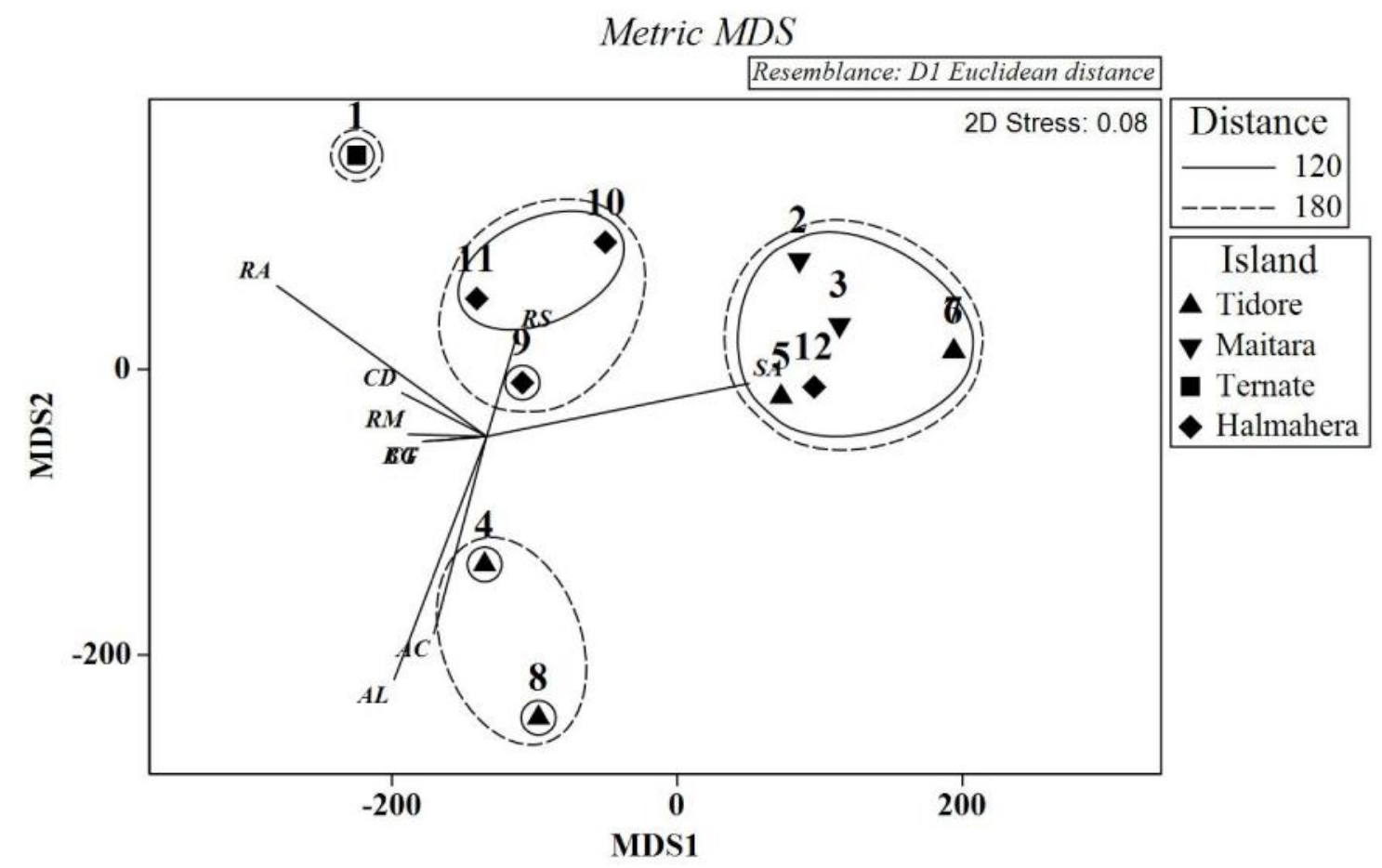

Gambar 5. Ordinasi MDS seluruh stasiun pemantauan berdasarkan nilai INP setiap spesies.

(SA=Sonneratia alba; $\mathrm{AL}=$ Avicennia lanata; $\mathrm{AC}=$ Aegiceras corniculatum; $\mathrm{RA}=$ Rhizophora apiculata; $\mathrm{RS}=$ Rhizophora stylosa $; \mathrm{RM}=$ R. mucronata; $\mathrm{BG}=$ Bruguiera gymnorrhiza; $\mathrm{CT}=$ Ceriops tagal; $\mathrm{CD}=C$. decandra)

Figure 5. MDS ordination of study sites based on each species's INP

( $\mathrm{SA}=$ Sonneratia alba; $\mathrm{AL}=$ Avicennia lanata; $\mathrm{AC}=$ Aegiceras corniculatum; $\mathrm{RA}=$ Rhizophora apiculata; $\mathrm{RS}=$ Rhizophora stylosa; $\mathrm{RM}=$ R. mucronata; $\mathrm{BG}=$ Bruguiera gymnorrhiza; $\mathrm{CT}=$ Ceriops tagal; $\mathrm{CD}=C$. decandra)

Tabel 3. Koefisien korelasi Pearson (Signifikansi) antara nilai persentase tutupan-kerapatan pohon dengan nilai INP setiap spesies mangrove.

Table 3. Pearson correlation coefisien (Significancy) between coverage-tree density and species INP.

\begin{tabular}{cccccccccccc}
\hline & COVERAGE & DENSITY & SA & AL & AC & RA & RS & RM & BG & CT & CD \\
\hline COVERAGE & 1.00 & 0.37 & -0.46 & -0.05 & -0.12 & $0.64^{*}$ & -0.41 & 0.21 & 0.15 & 0.15 & 0.34 \\
Sig. & & 0.24 & 0.13 & 0.87 & 0.71 & 0.02 & 0.19 & 0.51 & 0.63 & 0.63 & 0.29 \\
\hline DENSITY & 0.37 & 1.00 & $-0.60^{*}$ & 0.34 & -0.01 & 0.25 & 0.17 & 0.30 & 0.26 & 0.26 & 0.23 \\
Sig. & 0.24 & & 0.04 & 0.28 & 0.97 & 0.43 & 0.60 & 0.34 & 0.41 & 0.41 & 0.47
\end{tabular}

*: menunjukan hubungan yang signifikan pada alpha $=0.05$.

$*$ : showed significant correlation on alpha $=0.05$

Analisis korelasi Pearson menunjukkan bahwa nilai persentase tutupan berhubungan secara signifikan dengan keberadaan spesies $R$. apiculata (Pearson, $\mathrm{F}=0,64 ; \mathrm{P}=0,02)$. Sementara itu, nilai kerapatan yang rendah pada stasiun TTEM06 dan TTEM07 disebabkan oleh dominasi penuh spesies $S$. alba yang memiliki ukuran batang yang besar $(\mathrm{DBH}>30 \mathrm{~cm})$. Analisis korelasi (Pearson, $\mathrm{F}=-0,60 ; \quad \mathrm{P}=0,04)$ menunjukkan pengaruh $S$. alba yang cukup 
signifikan terhadap tren nilai kerapatan setiap stasiun penelitian.

\section{Pembahasan}

Berdasarkan Keputusan Menteri Lingkungan Hidup No. 201 tahun 2004 tentang Kriteria Baku dan Pedoman Penentuan Kerusakan Mangrove, nilai tutupan kanopi komunitas mangrove di Pulau Tidore dan pulau-pulau kecil sekitarnya mengindikasikan kondisi komunitas mangrove yang masih dalam kondisi yang cukup baik. Kondisi ini sama dengan beberapa lokasi pemantauan COREMAP CTI, yang menggunakan pendekatan hemispherical photography, yaitu: Wakatobi $(72,39 \pm 23,12 \%) ;$ Wayag/Raja Ampat (71,61 \pm 16,58\%); Kepulauan Aru/Maluku Tenggara (72,70 \pm $16,62 \%)$; dan Kendari $(68,02 \pm 8.68 \%$ ) (Dharmawan dan Pramudji 2017). Kondisi mangrove yang sangat baik ditemui di Wondama/Papua (Dharmawan dan Widyastuti 2017) dan Biak, Papua (Dharmawan 2016).

Sebaran komunitas mangrove menurut Prayudha (2012) di Pulau Ternate seluas 7,01 ha atau $0.07 \%$ dari total luas daratan Pulau Ternate. Berdasarkan acuan Keputusan Menteri Lingkungan Hidup No. 201 tahun 2004, kondisi mangrove di Pulau Ternate yang masih tersisa, yaitu stasiun TTEM01 termasuk dalam kondisi yang sangat baik dengan persentase tutupan sebesar $78.91 \pm 8.28 \%$. Kepadatan mangrove yang semakin meningkat, yakni 1.000 batang/ha dibandingkan kepadatan mangrove pada tahun 2012 di lokasi yang sama yang hanya 500 batang/ha (Dharmawan dan Purnomo 2012). Namun, keanekaragaman spesiesnya sangat rendah dan hanya didominasi oleh Rhizopora apiculata. Substrat yang berlumpur keras mendukung pertumbuhan spesies ini dengan baik. Tanaman ini tumbuh terbaik di daerah berpasir, berlumpur, tanah liat, dan kombinasi dari semuanya (Duke, 2006). Kondisi mangrove yang tergolong sangat baik di lokasi penelitian karena berdekatan dengan lokasi kawasan wisata alam Danau Tolired, dan rendahnya aktivitas warga terhadap perusakan hutan mangrove. Kondisi ini sangat berbeda di sebelah timur bagian selatan Pulau Ternate tidak ditemukan hutan mangrove karena aktivitas manusia yang sangat padat dan sebagai pusat kegiatan pemerintah Provinsi Maluku Utara.

Pulau Maitara adalah pulau yang memiliki luas mangrove 6 ha atau 2,05\% dari luas total daratannya (Prayudha 2012). Dua stasiun di Pulau Maitara, TTEM02 dan TTEM03 memiliki kemiripan komposisi spesies. Kedua stasiun ini didominasi oleh Sonneratia alba dengan tiga spesies di dalam transek. Substrat yang berlumpur dan berpasir ini banyak terdapat di ekosistem mangrove Pulau Maitara.
Tanaman Sonneratia alba tumbuh baik di daerah yang banyak terdapat campuran substrat sedimen lumpur dan pasir, berbatu, koral, dan kerikil di lokasi yang terlindung dari ombak yang kuat, juga di area muara dan jauh dari pantai lepas (Lee et al. 2015). Berdasarkan acuan Keputusan Menteri Lingkungan Hidup No. 201 tahun 2004, stasiun TTEM02 termasuk dalam kategori tutupan mangrove baik dengan persentase $61,02 \pm 21,20 \%$, sedangkan stasiun TTEM03 memiliki persentase tutupan kanopi $76,80 \pm 4,93 \%$ dan termasuk dalam kondisi sangat baik. Kepadatan mangrove yang semakin meningkat 1.233 batang/ha dan 1.317 batang/ha pada saat penelitian dilakukan, dibandingkan dengan tahun 2012 di lokasi yang sama hanya 800 batang/ha dan 483 batang/ha (Dharmawan dan Purnomo 2012). Kondisi mangrove tergolong sangat baik di Pulau Maitara karena aktivitas manusia masih sangat jarang di sekitar hutan bakau.

Pulau Tidore memiliki luas mangrove sebesar 9,07 ha atau $0,08 \%$ dari total luas daratannya (Prayudha 2012). Berdasarkan acuan Keputusan Menteri Lingkungan Hidup No. 201 tahun 2004, seluruh stasiun penelitian di Pulau Tidore termasuk dalam kondisi baik. Stasiun yang memiliki substrat berlumpur keras (TTEM04 dan TTEM08) didominasi oleh Avicennia lanata sedangkan pada substrat berpasir didominasi oleh spesies $S$. alba. Spesies Avicennia lanata lebih suka tumbuh di atas substrate agak berpasir dan berlumpur keras (Lee et al. 2015). Kepadatan mangrove yang semakin meningkat di empat stasiun (TTEM04, TTEM 05, TTEM 07, TTEM 08) pada tahun 2015, yakni masing-masing sebanyak 1.783 batang/ha, 1.200 batang/ha, 773 batang/ha, dan 1.267 batang/ha dibandingkan kepadatan mangrove pada tahun 2012 di lokasi yang sama berjumlah 450 batang/ha, 400 batang/ha, 900 batang/ha, dan 450 batang/ha (Dharmawan dan Purnomo 2012). Kepadatan mangrove di stasiun TTEM06 mengalami penurunan, yakni berjumlah 773 batang/ha pada saat penelitian dilaksanakan dibandingkan pada tahun 2012 yang berjumlah 1.950 batang/ha (Dharmawan and Purnomo 2012). Penurunan jumlah mangrove di Pulau Tidore saat penelitian dilaksanakan, dapat disebabkan oleh pembangunan pelabuhan perikanan untuk masyarakat nelayan di wilayah Pulau Tidore.

Empat stasiun monitoring hutan bakau di kawasan Pulau Halmahera memiliki kondisi yang berbeda. Berdasarkan acuan Keputusan Menteri Lingkungan Hidup No. 201 tahun 2004 stasiun penelitian kawasan pesisir Jailolo, Pulau Halmahera, memiliki kondisi mangrove yang sangat baik. Pada stasiun ini (TTEM09 dan TTEM10) memiliki persentase tutupan kanopi 75,78 $\pm 12,42 \%$ dan 78,05 $\pm 9,79 \%$. Kepadatan mangrove di stasiun TTEM09 
mengalami peningkatan pada tahun 2015 sebanyak 1.567 batang/ha dibandingkan pada tahun 2012 yang berjumlah 667 batang/ha (Dharmawan and Purnomo 2012). Stasiun TTEM09 memiliki keanekaragaman spesies yang paling tinggi, terdiri dari tujuh spesies dan didominasi oleh $R$. mucronata, di stasiun TTEM10 ditemukan tiga spesies mangrove dengan dominasi $R$. apiculata. Spesies R.apiculata tumbuh baik di atas substrat yang berlumpur keras, lembut, dan agak becek. $R$. mucronata memiliki karakteristik substrat yang sama dengan $R$. apiculata tetapi lebih toleran terhadap substrat yang berpasir dan lebih keras (Lee et al. 2015).

Dua stasiun penelitian lainnya di Dodinga (TTEM11) dan Kaiyasa (TTEM12) memiliki persentase tutupan kanopi yang tidak berbeda nyata (Nilai $\mathrm{P}>0,05$ ). Namun, persentase tutupan mangrove pada dua stasiun tersebut tergolong dalam kategori yang berbeda. Kondisi hutan mangrove di stasiun TTEM11 termasuk dalam kategori sangat baik $(78,93$ $\pm 11,96 \%$ ) sedangkan TTEM12 memiliki persentase tutupan 74,48 $\pm 9,36 \%$ yang termasuk dalam kategori baik. Kepadatan mangrove di stasiun TTEM11 dan TTEM12 mengalami peningkatan pada tahun 2015 masing-masing sebanyak 1.533 batang/ha dan 1.467 batang/ha, dibandingkan pada tahun 2012 berjumlah 640 batang/ha dan 1.110 batang/ha (Dharmawan and Purnomo 2012). Kondisi hutan mangrove yang terletak di Pulau Halmahera khususnya di Kabupaten Halmahera Barat ini tergolong sehat karena aktivitas manusia yang masih sangat jarang. Pemerintah daerah setempat perlu melakukan rencana tata ruang yang berkelanjutan untuk hutan mangrove karena sejak 2010 pemindahan Ibukota Provinsi Maluku Utara ke Sofifi dikhawatirkan akan merusak lingkungan yang termasuk salah satunya adalah hutan mangrove di kawasan tersebut.

\section{Kesimpulan}

Kondisi komunitas mangrove di wilayah perairan Pulau Tidore dan sekitarnya termasuk dalam kategori baik dengan rata-rata persentase tutupan kanopi sedang. Kondisi ini didukung oleh kerapatan pohon yang termasuk kategori sedang $(>1000$ pohon/ha). Secara keseluruhan, Sonneratia alba merupakan spesies paling mendominasi di dalam kawasan, diikuti oleh $R$. apiculata dan A. lanata dari sembilan spesies yang ditemukan dalam lokasi penelitian. Kondisi substrat sangat mempengaruhi komposisi spesies dalam komunitas.

\section{Ucapan Terima Kasih}

Ucapan terima kasih khusus disampaikan kepada Bapak Petrus Ch Makatipu, M.Si selaku koordinator kegiatan penelitian COREMAP CRITCLIPI 2015 di Pulau Ternate dan sekitarnya, atas kesempatan dan bimbingan dalam melakukan penelitian. Rekan-rekan Pusat Penelitian Oseanografi, Bapak Nebuchadnezzar Akbar dari Universitas Khairun Ternate dan staff teknisi Bapak Ahmad Muhammad di Stasiun Penelitian Lapangan Ternate, Maluku Utara yang telah membantu banyak tenaga dan waktu dalam melakukan kegiatan penelitian. Ibu Professor Dr. Gadis Sri Haryani atas bimbingan dalam membuat karya tulis ilmiah ini.

\section{Daftar Pustaka}

Akbar, N., A. Baksir and I. Tahir. 2015. Struktur Komunitas Ekosistem Mangrove Di Kawasan Pesisir Sidangoli Kabupaten Halmahera Barat , Maluku Utara Community Structure of Mangrove Ecosystem in Sidangoli Coastal of West Halmahera Regency, North Moluccas. DEPIK 4 (3): 132-43.

Alongi, D. M. 2009. The Energetics of Mangrove Forests. $1^{\text {st }}$ ed. Springer Netherland. DOI:10.1007/978-1-4020-4271-3.

Bouillon. S, Alberto V Borges, Edward CastanedaMoya, Karen Diele, Thorsten Dittmar, Norman C Duke, Erik Kristensen, Shing Y Lee, Cyril Marchand, Jack J Middleburg, Victor H. Rivera Monroy, Thomas J Smith III, Robert R Twilley. 2008. Mangrove Production and Carbon Sinks : A Revision of Global Budget Estimates. Global Biogeochemichal Cycles. 22 : 1-12. DOI : 10.1029/2007/GB003052

Cahoon, D. R., P. Hensel, J. Rybczyk, K. L. Mckee and E. Proffitt 2003. Mangrove Peat Collapse Following Mass Tree Mortality: Implications for Forest Recovery from Hurricane Mitch. Journal of Ecology 91: 1093-1105. DOI:10.1046/j.13652745.2003.00841.x.

Dharmawan, I.W.E. dan Purnomo. 2012. Kajian Keanekaragaman Spesies, Ekologi Komunitas, dan Stok Karbon Mangrove di Perairan Ternate, Tidore, dan Sekitarnya. p. 66-82 Dalam Giyanto ed. Ekosistem Pesisir Ternate, Tidore, dan Sekitarnya Provinsi Maluku Utara. CRITC-Pusat Penelitian Oseanografi LIPI, Jakarta. Indonesia,

Dharmawan, I.W.E. dan Pramudji. 2014. Panduan Monitoring Status Ekosistem Mangrove. Pramudji dan A. Nontji ed. $1^{\text {st }}$ ed. Jakarta: COREMAP CTI LIPI.

Dharmawan, I.W.E. 2016. Kondisi Komunitas Mangrove Terkini di KKPD Biak. Report. COREMAP-CTI, P2O-LIPI. 10pp

Dharmawan, I.W.E dan Pramudji. Mangrove status in Indonesia. In Prep

Dharmawan, I.W.E. dan A. Widyastuti. 2017. Pristine Mangrove Community in Wondama Gulf 
, West Papua, Indonesia. Marine Research

Indonesia 42 (2): 67-76.

DOI: $10.14203 / \mathrm{mri} . v 42 \mathrm{i} 2.175$.

Duke, N. C. 2006. Rhizophora apiculata, $R$. Mucronata, R. Stylosa, R. × Annamalai, R. × Lamarckii (Indo-West Pacific Stilt Mangroves). Species Profiles for Pasific Island

Agroforesty. April: 1-21.

www.traditionaltree.org.

Duke, N.C., J. O. Meynecke, S. Ditmann, A.M. Ellison, K. Anger, U. Berger, S. Cannicci, K. Diele, K. C. Ewel, C. D. Field, N. Koedam, S. Y. Lee, C. Marchand, I. Nordhaus, F. DahdouhGuebas. 2007. A World Without Mangrove? Science. 317 (July) : 41-43. DOI : 10.1126/ science. $317.5834 .41 \mathrm{~b}$

FAO. 2007. The World's Mangroves 1980-2005. FAO Forestry Paper 153. Rome.

Giesen, W., S. Wulffraat, M. Zieren and L. Scholten 2007. Mangrove Guidebook for Southeast Asia. DOI:10.1086/346169.

Giri, C., E. Ochieng, L. L. Tieszen, Z. Zhu, A. Singh, T. Loveland, J. Masek and N. Duke. 2011. Status and Distribution of Mangrove Forests of the World Using Earth Observation Satellite Data. Global Ecology and Biogeography 20 (1): 15459. DOI:10.1111/ j.1466-8238. 2010. 00584.x.

Lee, S. S., A. Muhammad and J. Tong. 2015. Mangrove, Guidebook for Malaysia. Edited by Flora George. $1^{\text {st }}$ ed. Selangor: Wetlands International, Malaysia.

Mitsch, W. J. and J. G Gosselink. 2015. Wetlands. Fifth. New Jersey: John Wiley \& Sons, Inc.

Nellemann, C., E. Corcoran, C. M. Duarte, L. Valdes, C. De Young, L. Fonseca, and G. Grimsditch. 2009. Blue Carbon. A Rapid Response Assessment. United Nations Environment Programme, GRID-Arendal. New York.

Prayudha, B. 2012. Pemetaan Sumberdaya Kepesisiran Melalui Teknologi Penginderaan Jauh si Perairan Ternate, Tidore, dan sekitarnya. p. 7-18 Dalam Giyanto ed. Ekosistem Pesisir Ternate, Tidore, dan Sekitarnya Provinsi Maluku Utara. CRITC-Pusat Penelitian Oseanografi LIPI. Jakarta. Indonesia.

Rahmantya, K.F., A.D. Asianto, D. Wibowo, T. Wahyuni dan W.A. Somad 2015. Kelautan dan Perikanan dalam Angka 2015. Pusat Data, Statistik dan Informasi Kementerian Kelautan dan Perikanan, Jakarta. 